\title{
PERSISTENT THROMBOCYTOPENIA IN DENGUE FEVER IS RARE BUT NOT UNCOMMON - CAN BE TREATED WITH STEROID SUCCESSFULLY
}

\author{
MD. DAHARUL ISLAM ${ }^{1}$, KHALEDA AKTER ${ }^{2}$ RANAJIT SEN CHOWDHURY ${ }^{3}$, MOHAMMAD ABDUS SATTAR \\ SARKAR $^{3}$, AMINUR RAHMAN ${ }^{4}$
}

\begin{abstract}
Fever, skin rash, thrombocytopenia and bleeding are common manifestation of dengue fever (DF). Thrombocytopenia usually gets better and platelet count normalizes by day 10 of fever. Chronic thrombocytopenia is not a feature of dengue fever. Proposed mechanisms behind thrombocytopenia are many. Direct platelet destruction by dengue virus, immune-mediated platelet destruction and evenmegakaryocytic immune injury are proposed as underlying mechanisms. We are reporting a caseof a 43 year old female who presented in dengue season in 2019 with fever and bleeding and wasdiagnosed as a case of dengue haemorrhagic fever. She had persistent thrombocytopenia which neededto be treated on the lines of immune thrombocytopenia and responded to steroids. Other causes of thrombocytopenia were ruled out.
\end{abstract}

Key wards: Dengue Fever (DF), Dengue Haemorrhagic Fever (DHF), Idiopathic Thrombocytopenic Purpura

Received: 28 November, 2020

Accepted: 25 December, 2020

DOI: https://doi.org/10.3329/bjm.v32i1.51097

\section{Background:}

Thrombocytopenia and haemorrhagic manifestations are consistent features of dengue fever (DF). Usually thrombocytopenia resolves by day 10 of fever. Very few cases have been reported worldwide there may be thrombocytopenia lasting more than ten days .All these reported cases behaved like immune thrombocytopenia (ITP) and improved completely with steroid therapy with prolonged maintenance of platelet counts. Usual thrombocytopenia of DF does not respond to steroids. Probably previous reports, including ours, indicate that dengue virus infection can produce a persistent thrombocytopenia is similar to immune mediated thrombocytopenia. If there is persistent thrombocytopenia after the fever dengue fever should be suspected, as treatment with steroids is highly effective.

\section{Case Presentation:}

A 43-year-old lady married, housewife, multipara, resident of Narayanganj presented to our hospital with complaints of high grade fever for five days and rashes in both lower limbs for two days. The fever was high grade, intermittent, associated with chills and rigor with generalized body ache and headache. There was no history of vomiting, seizure, altered consciousness, cough, expectoration or any features of urinary tract infection, bone pain or joint pain. She noticed that she had amenorrhea for 5 yrs. The patient did not receive any specific treatment except paracetamol for fever and pain. She did not have any comorbidity like hypertension, diabetes, ischemic heart disease. On admission, she was conscious, well oriented but febrile. Her pulse rate was 110/min(regular), Blood Pressure 100/70 mm of $\mathrm{Hg}$ (no orthostatic fall), Respiratory rate-16/min, Temperature-101.80 F. There were petechial rashes over Lower limbs. There was also mild ascites without any organomegaly. A Provisional clinical diagnosis of Dengue Feverwasmade based.

Haematological investigations at the time of admission revealed Hemoglobin-14.2 gm\% with Total Leukocyte Count (TLC) 4500 per cu. $\mathrm{mm}$, with differential Count (65\% Polymorphs, 31\% Lymphocytes, 02\%

1. Associate Professor, Dept of Medicine, Sir Salimullah Medical College.

2. Associate Professor, Dept of Gynae \& Obs, Z. H Sikder Medical College.

3. Associate Professor, Dept of Medicine, Sir Salimullah Medical College.

4. Assistant Professor, Dept of Neurology, Sir Salimullah Medical College.

Correspondence: Dr. Md. Daharul Islam, Associate Professor, Dept of Medicine, Sir Salimullah Medical College. Email: islamdaharul@yahoo.com

Bangladesh J Medicine 2021; 32 : 62-64 
Monocyte, Eosinophil 02\%): Hct (Haematocrit)- 46 and Platelet Count was 46,000 per cu mm. Renal and liver function tests, including serum electrolytes and urine microscopy, were within normal limits. Tests for malaria was negative. The serological test for dengue was IgM positive.

Initial treatment was given with intravenous (IV) fluids to maintain adequate hydration and oral paracetamol tablets for fever spikes according our National Dengue Guideline. Next day of admission, her platelet count further decreased to 20,000 per cu mm. On 3rd day of admission she became afebrile but her platelet count was 15,000 per cu $\mathrm{mm}$. As there was no active bleeding, we decided against platelet transfusions. She improved clinically and petechial lesions started resolving. She was discharged on $6^{\text {th }}$ day with platelet count of 55,000 per cu mm.

Two weeks after discharge she backed to the emergency department with complaints of petechial rashes over upper limbs and per vaginal bleeding for one day without any fever. Complete blood count showed a platelet count of 10,000 per cu $\mathrm{mm}$ but other parameters were normal. She was transfused one unit of fresh blood, her platelet count raised to 35,000 per cu $\mathrm{mm}$ and per vaginal bleeding stopped. This time, to search for any secondary cause of thrombocytopenia, bone marrow examination was done on $3^{\text {rd day }}$ of her admission that revealed adequate megakaryocytes without any other abnormality consistent with peripheral destruction of platelets. ANA (Antinuclear antibody) test done which was negative and tests for HIV, Hepatitis B and C were also negative. On 4thday of her second admission her platelet count again reduced to 15,000 per cu $\mathrm{mm}$.

Considering the possibility of immune mediated thrombocytopenia oral prednisolone was started at a dose of $1 \mathrm{mg} / \mathrm{kg}$ body weight on the 5 th day of $2 \mathrm{nd}$ admission. There was dramatic response after steroid administration and platelet count started improving.

\section{Outcome and Follow-Up:}

There was a rapid and progressive increase in platelet counts in next 4-5 days of starting steroid. Platelet count on 10th day -40,000, and on 12th day - 90,000. She was discharged on 13thday and was followed up. After 1 month, prednisolone dose was slowly tapered over a next -month period and were stopped. The patient maintained platelet counts in follow-up after 1 week interval for 1 st month, then 2 week interval for 2nd month and on monthly follow-up for another month. Monitoring of Platelet count in hospital stay and OPD follow-up is shown in the figure 1.

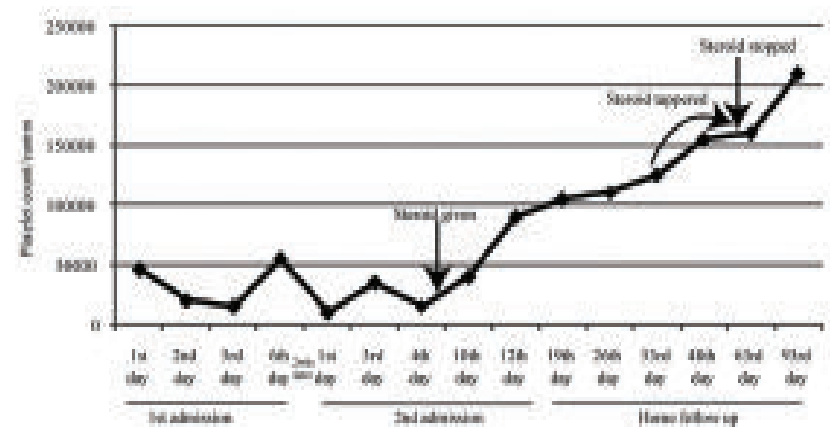

Fig.-1: Platelet count trend in hospital stay and OPD follow-up. The 1 st arrow indicates the start of Prednisolone and 2nd arrow indicates stopping after tapering.

\section{Discussion:}

Several recent studies have searched the causes of thrombocytopenia in dengue. Laboratory and human studies have revealed a direct correlation between activation and depletion of platelets, with a sharp drop occurring on day 4 of fever. Lots of Dengue virus genome is found in activated thrombocytes. Increased binding of complement $\mathrm{C} 3$ and Ig G have also been found on the surface of these platelets. In addition to platelet activation, dengue infection has been found to activate the intrinsic pathway of apoptosis, with increased surface phosphatidylserine exposure, mitochondrial depletion, and activation of caspase 3 and $9 .{ }^{1}$

Thrombocytopenia associated with viral infection appears to result from both a decrease in platelet production from megakaryocytes and a reduction in the half-life of platelets. The latter is the principal mechanism. ${ }^{2}$ Platelets that are sensitized by autoantibodies are destroyed by cells of the reticuloendothelial system, particularly those of the spleen. ${ }^{3,}{ }^{4}$ These autoantibodies against glycoproteins of the platelet membrane can be identified in $80 \%$ of the patients. ${ }^{5,6}$. A variety of viruses have already been implicated in the etiopathogenesis of ITP, especially in children: HIV_- ${ }^{7,8}$, hepatitis C virus9, Varicella-Zoster virus ${ }^{10,11}$, rubella ${ }^{12,13}$,influenza ${ }^{14}$ and Epstein-Barr virus $^{15}$.

Platelet count usually reaches its lowest level as the patient is about to recover, that is, about 1 week after the onset of fever and more than $70 \%$ of patients show recovery of their platelet count after that. It recovers promptly in the ensuing week, usually on day 9 th to 11 th of illness. In the natural history of illness all the patients show convalescence and platelet count recovers to the pre illness level. ${ }^{16}$ Our patient had a 
platelet count of $10000 / \mathrm{mm} 3$ at day 25 from 1 st day of fever and responded to prednisolone promptly. Only a few case reports described persistent thrombocytopenia in patients with DF. Leong has reported corticosteroid responsive prolonged thrombocytopenia in a 15 year-old Chinese boy. The patient was successfully treated with steroids tapered over 3 months without any relapse for 6 months. ${ }^{17}$ Bhalla et al reported a 34-year-old woman who had persistent thrombocytopenia for more than 10 days with bleeding manifestations and responded well to steroids. ${ }^{18}$ Luiz Jose'de Souza et al has reported a 46-year-old woman with a dengue virus infection with prolonged ITP which responded to steroids. ${ }^{19}$

\section{Conclusion:}

Thrombocytopenia following dengue is common but is usually transient. Persistent thrombocytopenia israre but not uncommon in dengue feverand usually responds to steroid therapy. Our patient showed response to steroids and recovered after starting of steroid. Response to steroid in this case confirms the fact that pathogenesis of thrombocytopenia in dengue is predominantly immunologic. If any patient with persistent thrombocytopenia who has history of fever in recent past, Dengue infection should be ruled out.

\section{References:}

1. Hottz ED, Oliveira MF, Nunes PC, Nogueira RM; Vallsde-Souza R, Da Poian AT, et al. Dengue induces platelet activation, mitochondrial dysfunction and cell death through mechanisms that involve DC-SIGN and caspases. J Thromb Haemost2013; 11(5):951-62. https://doi.org/10.1111/jth.12178 PMid:23433144 PMCid:PMC3971842

2. Rand ML, Wright JF. Virus-associated idiopathic thrombocytopenic purpura. TransfusSci 1998; 19(3): 253-259. https://doi.org/10.1016/S09553886(98)00039-3

3. Harrington WJ, Minnich V, Arimura G. The autoimmune thrombocytopenia. In Tocantins M (Ed.): Progress in hematology. New York, Grune\&Stratton, 1956: pp 166L-176L.

4. Karpatkin S. Autoimmune (idiopathic) thrombocytopenic purpura. Lancet1997; 359(9064): 1531-1536. https://doi.org/10.1016/S0140-6736(96)12118-8

5. Berchtold $\mathrm{P}$ and Wenger M. Autoantibodies against platelet glycoproteins in autoimmune thrombocytopenic purpura: Their clinical significance and response to treatment. Blood.1993; 81(5): 1246-1250 https:// doi.org/10.1182/blood.V81.5.1246.bloodjournal 8151246 PMid:8443385

6. He R, Reid DM, Jones CE and Shulman NR. Spectrum of Ig classes, specificities, and titers of serum antiglycoproteins in chronic idiopathic thrombocytopenic purpura. Blood.1994; 83(4): 1024-1032. https://doi.org/10.1182/blood.V83.4. 1024. 1024
PMid:8111044

7. Ellaurie M, Burns ER, Bernstein LJ, Shah K and Rubinstein A. Thrombocytopenia and human immunodeficiency virus in children. Pediatrics. 1988; 82(6): 905-908.

8. Kouri YH, Borkowsky W, Nardi M, Karpatkin S and Basch RS. Human megakaryocytes have a CD4 molecule capable of binding human immunodeficiency virus-1. Blood.1993; 81(10): 2664-2670. https:// doi.org/10.1182/blood.V81.10.2664. bloodjournal 81102664 PMid: 8490176

9. Cines DB, Blanchette VS. Immune thrombocytopenic purpura. N Engl J Med 2002; 346(13): 995-1008. https://doi.org/10.1056/NEJMra010501 PMid: 11919310

10. Espinoza C, Kuhn C. Viral infection of megakaryocytes in varicella with purpura. Am J ClinPathol 1974; 61(2): 203-208. https://doi.org/10.1093/ajcp/61.2.203 PMid:4855807

11. Winiarski J. Platelet antigens in varicella associated thrombocytopenia. Arch Dis Child.1990; 65(1): 137139. https://doi.org/10.1136/adc.65.1.137 PMid: 2301979 PMCid:PMC1792405

12. Morse EE, Zinkham WH, Jackson DP. Thrombocytopenic purpura following rubella infection in children and adults. Arch Intern Med. 1966; 117(4): 573-579. https://doi.org/10.1001/archinte. 1966.03870100101018

13. Perlman EC. Purpura and cerebral manifestations following measles. Arch Pediatr.1934; 51: 596-604.

14. Terada H, Baldini M, Ebbe S and Madoff MA. Interaction of influenza virus with blood platelets. Blood.1966; 28(2): 213-228. https://doi.org/10.1182/ blood.V28.2.213.213 PMid:5913052

15. Grossman LA and Wolff SM. Acute thrombocytopenic purpura in infectious mononucleosis. JAMA.1959; 171: 2208-2210. https://doi.org/10.1001/jama.1959. 73010340001013 PMid:13829701

16. Putintseva E, Vega G, Fernandez L. Alterations in thrombopoiesis in patients with thrombocytopenia produced by dengue hemorrhagic fever. Nouv Rev Fr Hematol 1986; 28:269-73.

17. Leong KW, Srinivas P. Corticosteroid-responsive prolonged thrombocytopeniafollowing dengue hemorrhagic fever. Med J Malaysia1993; 48:369-72

18. Bhalla A, Bagga R, Dhaliwal LK,et al. Steroid responsive prolongedthrombocytopenia in Dengue. Indian J Med Sci 2010; 64:90-3. https://doi.org/10.4103/00195359.94406 PMid:22466499

19. De Souza LJ, Neto CG, Bastos DA,et al. Dengue and immune thrombocytopenic purpura. WHO Dengue Bull2005; 29:136-49. 